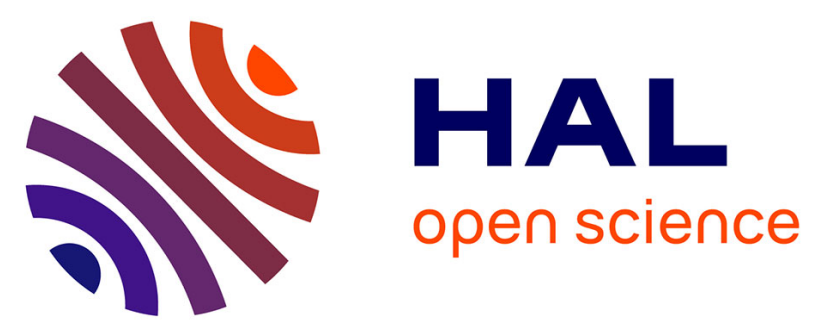

\title{
Assessing the suitability of recovering shrub biowaste involved in wildland fires in the South of Europe through torrefaction mobile units
}

María González Martínez, Capucine Dupont, Denilson da Silva Perez, Luis Míguez-Rodríguez, Maguelone Grateau, Sébastien Thiéry, Tarja Tamminen, Xuan Mi Meyer, Christophe Gourdon

\section{To cite this version:}

María González Martínez, Capucine Dupont, Denilson da Silva Perez, Luis Míguez-Rodríguez, Maguelone Grateau, et al.. Assessing the suitability of recovering shrub biowaste involved in wildland fires in the South of Europe through torrefaction mobile units. Journal of Environmental Management, 2019, 236, pp.551-560. 10.1016/j.jenvman.2019.02.019 . hal-02283660

\section{HAL Id: hal-02283660 https://hal.science/hal-02283660}

Submitted on 11 Sep 2019

HAL is a multi-disciplinary open access archive for the deposit and dissemination of scientific research documents, whether they are published or not. The documents may come from teaching and research institutions in France or abroad, or from public or private research centers.
L'archive ouverte pluridisciplinaire HAL, est destinée au dépôt et à la diffusion de documents scientifiques de niveau recherche, publiés ou non, émanant des établissements d'enseignement et de recherche français ou étrangers, des laboratoires publics ou privés. 


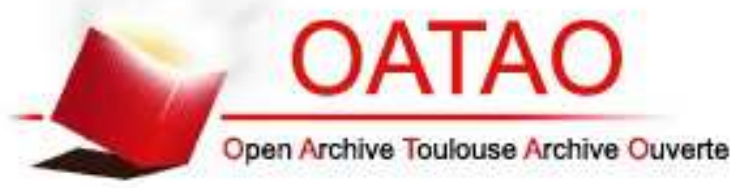

\section{Open Archive Toulouse Archive Ouverte}

OATAO is an open access repository that collects the work of Toulouse researchers and makes it freely available over the web where possible

This is an author's version published in: http://oatao.univ-toulouse.fr/24261

\section{Official URL:}

https://doi.org/10.1016/j.jenvman.2019.02.019

\section{To cite this version:}

González Martínez, María and Dupont, Capucine and da Silva Perez, Denilson and Míguez-Rodríguez, Luis and Grateau, Maguelone and Thiéry, Sébastien and Tamminen, Tarja and Meyer, Xuân-Mi and Gourdon, Christophe Assessing the suitability of recovering shrub biowaste involved in wildland fires in the South of Europe through torrefaction mobile units. (2019) Journal of Environmental Management, 236. 551-560. ISSN 0301-4797

Any correspondence concerning this service should be sent to the repository administrator: tech-oatao@listes-diff.inp-toulouse.fr 
Research article

\title{
Assessing the suitability of recovering shrub biowaste involved in wildland fires in the South of Europe through torrefaction mobile units
}

\author{
María González Martínez ${ }^{\mathrm{a}, \mathrm{b}, \mathrm{c}, *}$, Capucine Dupont ${ }^{\mathrm{d}}$, Denilson da Silva Perez ${ }^{\mathrm{e}}$, \\ Luis Míguez-Rodríguez ${ }^{\mathrm{f}}$, Maguelone Grateau ${ }^{\mathrm{a}}$, Sébastien Thiéry ${ }^{\mathrm{a}}$, Tarja Tamminen ${ }^{\mathrm{g}}$, \\ Xuân-Mi Meyer ${ }^{\mathrm{b}, \mathrm{c}}$, Christophe Gourdon ${ }^{\mathrm{b}, \mathrm{c}}$ \\ ${ }^{a}$ Université Grenoble Alpes, CEA, Laboratoire de Préparation des Bioressources (LPB), F-38000 Grenoble, France \\ ${ }^{\mathrm{b}}$ Université de Toulouse, INPT, UPS, Laboratoire de Génie Chimique, 4 Allée Emile Monso, F-31030 Toulouse, France \\ ${ }^{\mathrm{c}}$ CNRS, Laboratoire de Génie Chimique, F-31030 Toulouse, France \\ ${ }^{\mathrm{d}}$ IHE Delft Institute for Water Education, Department of Environmental Engineering and Water Technology, Delft, the Netherlands \\ ${ }^{\mathrm{e}}$ FCBA, InTechFibres Division, CS 90251, 38044 Grenoble, France \\ ${ }^{\mathrm{f}}$ Consellería de Educación e Ordenación Universitaria, Xunta de Galicia, Spain \\ ${ }^{\mathrm{g}}$ VTT Technical Research Centre of Finland Ltd, P.O. Box 1000, FI-02044, Finland
}

A R T I C L E I N F O

Keywords:

Torrefaction

Solid mass loss

Shrubs

Oak

Wildland fire

Volatile species

\begin{abstract}
A B S T R A C T
Several types of shrubs and oak inducing high wildland fire risk in the South of Europe were evaluated for their potential valorization through torrefaction. Biomasses were firstly characterized in terms of macromolecular and elemental composition. Lab-scale TGA-GC/MS torrefaction experiments allowed the in-depth study of the solid mass transformation and the production profile of 23 volatile species $\left(200\right.$ to $300{ }^{\circ} \mathrm{C}$ at $3^{\circ} \mathrm{C} \cdot \mathrm{min}^{-1}$ and $300{ }^{\circ} \mathrm{C}$ for $30 \mathrm{~min}$ ). The proportion of the torrefied p roducts ( solid, $\mathrm{CO}, \mathrm{CO}_{2}$, w ater a nd v olatile s pecies) $\mathrm{w}$ as evaluated through mass balance in a lab-scale furnace under typical torrefaction conditions $\left(300^{\circ} \mathrm{C}, 40 \mathrm{~min}\right)$. The results show a similar characterization and behavior in torrefaction for oak and shrublands, and slightly different characteristics for fern. However, fern may grow separately from shrublands and is considered to present a low fire risk. This suggests that the in-situ direct valorization of these biomasses through torrefaction m obile units seems promising. However, other properties, such as density, flowability and grindability need to be studied to confirm the feasibility of the p rocess. R egarding t orrefaction p roducts, a higher c arbon c ontent a nd a $\mathrm{n}$ interesting increase in heating value were measured for the torrefied solid, which $\mathrm{m}$ akes it suitable for energetic valorization, among other uses. The composition of permanent gases was evaluated and found in agreement with previous studies. Finally, the volatile species released were studied in function of the torrefaction temperature, in view of their possible valorization as green chemicals.
\end{abstract}

\section{Introduction}

Wildland fires have devastated increasing areas in Europe in the last years, especially in the Mediterranean countries. The extreme climate conditions such as extended heat waves, droughts or storms, combined with the abandon of part of the land area previously dedicated to the primary sector, strongly contribute to increase the risk of wildfires (SanMiguel-Ayanz et al., 2017).

In Spain, nearly 180,000 ha of forest burnt in 2017, mainly because of the dry climatic conditions in the second half of the year, which represents about twice the average of the previous 10 years. Of this forest surface, $37.5 \%$ corresponded to woody areas, $56.1 \%$ to shrubs and open woodland and the rest to grazing lands. Geographically, $73.8 \%$ of the total burnt forest area corresponds to the Northwest region, in particular the region of Galicia (Centro de Coordinación de la Información Nacional sobre Incendios Forestales, 2017). This could be explained by the fact that Galicia is the Spanish region with the highest annual increase of its biomass volume (Blanco Casal et al., 2017).

Diverse solutions and preventive plans have been proposed to fight against wildland fires, such as allowing controlled fires to reduce forest fuel and create discontinuities in the vegetation. Controlled burning is also used to improve the quality of pasture land by promoting desirable forage plant species. Even if there is a carbon footprint of controlled burning, which is especially remarkable when this technique is applied

\footnotetext{
* Corresponding author. Université Grenoble Alpes, CEA, Laboratoire de Préparation des Bioressources (LPB), F-38000 Grenoble, France.

E-mail address: maria.gonzalez-martinez@outlook.com (M. González Martínez).
} 
at a large scale, burning can also stimulate plant growth and carbon uptake (San-Miguel-Ayanz et al., 2017).

Biomass removal via valorization may successfully reduce biomass available for burning in wildland fires, which may be particularly useful in areas with a high fire hazard. Consequently, the accessibility of these areas may be improved and shepherding activities can be restored, as they have traditionally regulated biomass in the rural environment, protecting it from fires. N evertheless, the technology required for this biowaste valorization needs to face with the dispersion, the seasonality and the irregularity of biomass production. A mobile treatment technology was identified a s h elpful $t$ o d eal $w$ ith $t$ hese $c$ haracteristics of biomass waste production, avoiding transportation costs and logistics, as well as to provide a valorization solution with a direct impact at local scale (Tamminen et al., 2016).

Torrefaction consists of a mild thermochemical conversion process, suitable for dry biomasses, that is, below around $60 \%$ moisture before harvesting. It typically occurs between 200 and $300{ }^{\circ} \mathrm{C}$ during a few tens of minutes in a default-oxygen atmosphere (Bergman et al., 2015). The mild conditions of the process, as well as its robustness proved at industrial scale (Cremers et al., 2015; E4tech, 2009; Miguel Carneiro Ribeiro et al., 2018; Simbeck, 1993), suggest torrefaction as a suitable process for biomass waste conversion through mobile units.

The torrefied solid produced has properties closer to coal in terms of heating value, carbon content, hydrophobicity, grindability as well as flowability (Bridgeman et al., 2008). Some studies have pointed out the role of the torrefied solid and pyrolysis biochar in dealing with climate change, as it is suitable for carbon sequestering, while it can simultaneously provide energy and increasing crop yields (Woolf et al., 2010). Even if the torrefied product has been traditionally used for energetic purposes such as combustion, co-combustion and gasification (Bergman et al., 2015; Bridgeman et al., 2008; Fisher et al., 2012; Pach et al., 2002), it can contribute to soil regeneration and amendment, due to its hydrophobic capacity and mineral content (Kavitha et al., 2018; Rasa et al., 2018; Yu et al., 2019). This use would be related to the traditional clearing of these shrub areas through controlled fires that kept the burnt material on the soil, which was known to improve the quality of the growing pasture (Míguez Rodríguez, 2010). Finally, the torrefied product can be pelletized to be easier transported and easier to handle (Agar, 2017; García et al., 2018). In all these cases, a local use of the torrefied $\mathrm{p}$ roduct $\mathrm{o}$ btained $\mathrm{f}$ rom $\mathrm{t}$ he $\mathrm{s}$ hrub $\mathrm{b}$ iowaste $\mathrm{v}$ alorization is possible.

During torrefaction, condensable coproducts are released, which can damage the installation but may also be source of green chemicals (Lê Thành et al., 2015; Nocquet et al., 2014a). However, it is noteworthy that the diverse chemical composition of the condensable fraction released in torrefaction constitutes an analytical challenge to separate its constituents. The study of this fraction by chemical families allows identifying possible uses of the mixture, generally instead of considering the extraction of one single component (Detcheberry et al., 2016). For example, acetic acid has been pointed out as a green herbicide (Evans et al., 2011) that does not persist in the environment (Fischer and Kuzyakov, 2010).

Previous studies and projects have characterized biomasses susceptible to be involved in wildland fires in the South of Europe, in terms of availability and of energetic potential (Bados et al., 2016; Pérez et al., 2014). In some cases, the suitability of these biomasses was directly tested in combustion boilers (Mediavilla et al., 2017; Viana et al., 2012). In other cases, the production of pellets for energy purposes was also considered as an alternative (Vega-Nieva et al., 2016). The results of these studies have pointed out that this shrub biowaste appears as a promising resource for energetic valorization, due to its acceptable and stable high heating value as raw material ( $\mathrm{HHV}, \sim 20 \mathrm{MJ} \mathrm{kg}^{-1}$ ) and its high availability (G onzález-G onzálezet al., 2017; Núñez-Regueira et al., 2004). However, up to now, the suitability of transforming shrub biowaste through thermochemical conversion has only been briefly studied in the literature for brooms (Cytisus multiflorus, Pterospartum tridentatum) and for fern (Pteridium aquilinum) (Saldarriaga et al., 2015).

The objective of this work is to assess the possibility of valorizing through torrefaction mobile units six biomasses with a high risk of being involved in wildland fires in the South of Europe. To do this, biomasses are deeply characterized at lab-scale in terms of macromolecular and elemental composition, solid transformation kinetics and gaseous species release in torrefaction, including the mass balance of the torrefaction products. The behavior in torrefaction of the biomasses of study is linked to their macromolecular composition, so as to explain how their transformation happens and to estimate the yield of the solid product and the volatile species released in function of the operating conditions.

\section{Geographical context}

The selected case study corresponds to Serra de Queixa, a mountainous area included in the Central Massif in Ourense (Galicia), in the North-West of Spain.

\subsection{Description of the vegetation cover}

The vegetation cover of Serra de Queixa is non-uniform and distributed in altitudinal strips. It presents remarkable variations due to the anthropogenic action and to its geographical situation, between the Eurosiberian and the Mediterranean regions (Míguez Rodríguez, 2010).

At low altitudes, from 700 to $1200 \mathrm{~m}$, the vegetation is based on deciduous forests mainly of birch (Betula alba) and Pyrenean oak (Quercus pyrenaica), which alternate with mowing pastures. The development of the Pyrenean oak forests is favorable due to the siliceous soils, which acceptably resist frost and drought, and was typically used by its capacity of abundantly supply good quality wood (López González, 2006). Small riparian forests of maples (Acer pseudoplatanus), hazel trees (Corylus avellana) and scattered and sparse patches of relict holly trees (Ilex aquifolium) can also be found (Míguez Rodríguez, 2010).

Above $1200 \mathrm{~m}$, the area is cleared and currently deforested of the oak forest. The traditional clearing of the mountain allowed converting the area into pasture land, enhancing the natural forage grasses (Nardus stricta) and obtaining arable land for the cultivation of rye (Secale cereale). The clearing of the mountains let the place to Mediterranean high mountain scrubland, mainly composed of heather and broom. The area affected by this practice is of approximately 9000 ha in the area of study and is estimated to be around $25 \%$ of the total vegetation cover in the region (Míguez Rodríguez, 2010). The most abundant heather species are Mediterranean heathlands, especially the association PterospartoEricetum australis (Bellot Rodríguez, 1966). This heathland type grows in very poor and shallow soils, acting in soil retention and preventing erosion. Brooms are quickly developed in the places without competition with other species. They are Fabaceae or Papilionoideae species of the genus Cytisus and Genista, which includes Cytisus multiflorus, Cytisus striatus and Cytisus scoparius. At higher altitudes, they are replaced by Genista florida and on the peaks by Genista obtusirramea. Fern (Pteridium aquilinum) and gorse (Ulex minor) also appear mixed to these plants in variable ratios.

The top of the mountains ( 1500 to $1750 \mathrm{~m}$ ) are characterized by a succession of gentle slopes, where the abundant precipitation facilitates the appearance of well-drained wet surfaces suitable for natural pastures growing.

\subsection{Incurrence in wildland fires}

Herbaceous species, such as fern (Pteridium aquilinum), present a high water content, as they typically grow in wet areas, and a high flammability. Fern can be at the origin of fires, especially in dry weather conditions, but it does not contribute to maintain them, due to its low biomass content. As a result, its risk of being the cause of 
wildland fires is low.

Shrublands, including brooms (Cytisus spp), heather (Erica spp) and gorse (Ulex europaeus), are characterized by a high combustible mass content, while their water content is low. Their high flammability is propitious to start wildland fires i $\mathrm{nd}$ ryw eather conditions. Furthermore, their compact woody structure maintains the combustion and favors a quickly propagation of the fire. Their risk of being involved in wildland fires is high, as well as their occurrence in the area of study.

Oak (Quercus pyrenaica) is the most abundant woodland specie. It usually suffer a partial and superficial burn in wildland fires, including bark and superficial tissue layers. It c an s urvive a fter a non-prolonged exposition to fire, by quickly recovering from the root to the carbonized branches (Míguez Rodríguez, 2010).

\section{Materials and methods}

\subsection{Selected biomasses}

Six biomasses were selected in order to cover the diversity of lignocellulosic biomass of the investigated region. The large availability of these biomasses, as well as their ability of spreading and sustaining fire across the landscape, constitute interesting arguments for assessing their potential of recovery through thermal processes.

The selected biomasses include:

- five underexploited solid biofuels from shrublands: white broom (Cytisus multiflorus), yellow broom (Cytisus scoparius), heather (Erica australis), fern (Pteridium aquilinum) and gorse (Ulex europaeus),

- and a deciduous tree: Pyrenean oak (Quercus pyrenaica).

Oak was included in this study, together with shrublands, because of its high mismanaged production and low quality for furnishing or construction, as it is typically thin and presents twisted trunks. For the 6 biomasses, the whole plant is considered, including trunks, branches, leaves and flowers. Several plants of each specie were sampled for constituting a representative set per biomass.

Biomasses were harvested in the North-West of Spain (Chandrexa de Queixa, Ourense) during the summer 2016. They were shredded to 2-3 $\mathrm{mm}$ particle size and then spread in a dry place for air drying in ambient conditions for 14 days. This operation was carried out to mimic the typical extraction of this kind of shrubs and wood in the region, as they are typically cut and let in the field for a natural drying before collecting them. Then, drying in a convective oven was performed at $105^{\circ} \mathrm{C}$ during $24 \mathrm{~h}$. Two successive grinding operations were carried out on the dried biomass: a first grinding step with a Universal cutting mill Retsch (Retsch GmbH, Haan, Germany) equipped with a $1.5 \mathrm{~mm}$ grid and a second grinding step with a Universal cutting mill Fritsch Pulverisette 14 (Fritsch GmbH, Idar-Oberstein, Germany) equipped with a $0.5 \mathrm{~mm}$-grid.

\subsection{Experimental procedure}

\subsubsection{TORNADE device}

Mass balance torrefaction experiments were carried out in the TORNADE device, described in detail in (Nocquet et al., 2014a). This device was specifically designed to measure gas and condensable species yields. The reactor consists of a cylindrical crucible of $2.5 \mathrm{~cm}$ diameter and $5 \mathrm{~cm}$ height. It is placed inside the isothermal zone of a furnace. During the experiments, a preheated nitrogen flow of $1 \mathrm{~L} \cdot \mathrm{min}^{-1}$ (STP) is introduced at the bottom of the reactor through a porous media which ensures a homogeneous distribution. A mass of around $200 \mathrm{mg}$ of sample was placed in a stainless steel crucible of $2.5 \mathrm{~cm}$ diameter. At the top of the reactor, gas and condensable species were sent through a heated line to a Fourier Transformed Infra-Red (FITR) analyzer $\left(150^{\circ} \mathrm{C}\right)$ for online measurement of the permanent gases (Nocquet et al., 2014a). Then, the condensable part was collected in two cooled vessels, one at $0{ }^{\circ} \mathrm{C}$ (inside a cooling bath containing freezing ice) and one at $-70^{\circ} \mathrm{C}$ (in a cooling bath containing frozen carbon dioxide mixed with isopropanol). Wool was included in these vessels to increase the surface of exchange. The solid, the cooling baths and the intermediate pipes between the reactor and the cooling baths were weighed before and after experiment.

Torrefaction was carried out under isothermal conditions, at $300{ }^{\circ} \mathrm{C}$ for $40 \mathrm{~min}$. The selected torrefaction temperature was reached by a $30{ }^{\circ} \mathrm{C} \cdot \mathrm{min}^{-1}$ heating rate. Chemical regime was checked to be reached under these operating conditions (Nocquet, 2012).

The uncertainty in the estimated mass of the products was calculated as the semi-difference between two experiments. It is below $2 \%$ for the estimated yield of the torrefied solid and permanent gases and around $5 \%$ for the condensable species. The mass balance was fulfilled between 97 and $104 \%$. These values were found to be very satisfactory as they are below the systematic error, estimated to be between 3 and $5 \%$.

\subsection{2. $T G A-G C / M S$}

Torrefaction experiments were performed in a thermogravimetric analyzer (TGA, 92-16.18 SETARAM TGA 92). About $100 \mathrm{mg}$ of biomass sample were loaded in a three-plate crucible of $10 \mathrm{~mm}$ of diameter and $2 \mathrm{~mm}$ of bed thickness per plate, which was suspended into the TGA oven. The position of the three-place crucible in the TGA oven was checked to guarantee the same thermal behavior in the three biomass layers.

Samples were torrefied under a $50 \mathrm{~mL} \cdot \mathrm{min}^{-1}$ helium flow in the thermobalance. Each sample was firstly pre-heated from room temperature to $200^{\circ} \mathrm{C}$ at $3{ }^{\circ} \mathrm{C} \cdot \mathrm{min}^{-1}$. The selected temperature for the beginning of torrefaction was $200^{\circ} \mathrm{C}$, as the mass loss until this temperature can be considered as negligible. Then, the sample was torrefied from 200 to $300^{\circ} \mathrm{C}$ at $3^{\circ} \mathrm{C} \cdot \mathrm{min}^{-1}$, followed by an isothermal torrefaction step at $300^{\circ} \mathrm{C}$ for $30 \mathrm{~min}$. Helium was chosen as the carrier gas instead of nitrogen because of the analysis in GC/MS of the gases released during torrefaction. These operating conditions were selected so as to ensure the chemical regime in the experiments (González Martínez et al., 2016).

For each torrefaction experiment, the volatile species released were sampled each $10^{\circ} \mathrm{C}$ between 200 and $300^{\circ} \mathrm{C}$ and stored in a heated storage loop system (Chromatostock, Antelia). Then, each volatile fraction was analyzed in a GC/MS (Perkin-Elmer Clarus 580/Clarus SQ8S, EI ion source, split-less injection). The chromatogram analysis allowed to detect 55 chemical species $(\mathrm{m} / \mathrm{z}=28-300$, NIST library for the identification), from which 23 species were quantified thanks to calibrations with chemical standards.

Solid mass evolution was obtained considering the thermogravimetric data recorded every 10s. The profiles of volatile species production were traced considering an instantaneous gaseous sampling every $10^{\circ} \mathrm{C}$ for the non-isothermal torrefaction (11 points). The repeatability of torrefaction experiments was checked by carrying out twice each experiment in TGA-GC/MS. The relative error was found to be of around $2 \%$ for the thermogravimetric analysis and between 15 and $20 \%$ for the volatile species quantification. This latter result is considered acceptable because of the small amounts of volatile compounds to be measured.

\section{Results and discussion}

\subsection{Biomass characterization}

Moisture was evaluated by comparing biomass before and after the convective drying (Table 1). Moisture content was low, due to the 14days air drying in ambient conditions. The original moisture content of biomass, after harvesting and before natural drying, would be much higher, around 50\%, except for oak, around 30\% (USDA, 2010; Viana et al., 2012). 
Table 1

Biomass characterization.

\begin{tabular}{|c|c|c|c|c|c|c|c|}
\hline Composition & Method & Fern & Gorse & Heather & Oak & White broom & Yellow broom \\
\hline \multicolumn{2}{|c|}{ Physical properties } & \multicolumn{6}{|l|}{$\% w$} \\
\hline Moisture content & NF EN 14774 & 11.8 & 9.0 & 13.3 & 14.8 & 11.3 & 17.3 \\
\hline \multicolumn{2}{|c|}{ Macromolecular composition } & \multicolumn{6}{|c|}{$\% w m f$} \\
\hline Polysaccharides & TAPPI T249 cm-85 & 45.4 & 47.1 & 41.1 & 50.7 & 60.2 & 67.8 \\
\hline Lignin & TAPPI T222om-83/T222 om-84 & 30.1 & 30.0 & 35.9 & 25.3 & 25.0 & 22.1 \\
\hline Extractives & da Silva Perez et al. (2015) & 15.1 & 14.5 & 18.3 & 14.0 & 11.8 & 7.4 \\
\hline Ash & XP CEN/TS 14775 & 4.5 & 1.4 & 1.3 & 3.6 & 1.2 & 1.3 \\
\hline \multicolumn{2}{|l|}{ Mass balance } & 95.0 & 93.0 & 96.6 & 93.7 & 98.2 & 98.5 \\
\hline \multicolumn{2}{|c|}{ Neutral sugars composition of polysaccharides (normalized to $100 \%$ ) } & \multicolumn{6}{|l|}{$\%$} \\
\hline Glucose & TAPPI T249 cm-85 & 65.3 & 64.3 & 58.6 & 60.5 & 60.8 & 65.1 \\
\hline Xylose & & 16.5 & 24.8 & 33.1 & 28.8 & 30.5 & 30.7 \\
\hline Mannose & & 13.8 & 0.0 & 0.0 & 0.0 & 0.0 & 0.0 \\
\hline Galactose & & 2.7 & 4.2 & 4.8 & 4.9 & 3.1 & 1.7 \\
\hline Arabinose & & 1.7 & 6.7 & 3.6 & 5.7 & 5.6 & 2.5 \\
\hline \multicolumn{2}{|c|}{ Functional groups } & \multicolumn{6}{|c|}{$\% w m f$} \\
\hline Acetyl & da Silva Perez et al. (2015) & 3.7 & 4.8 & 5.8 & 5.5 & 5.9 & 6.7 \\
\hline
\end{tabular}

\%w: mass percentage; \% wmf: weight-moisture-free; \% of the total monosugars.

Table 2

Biomass main inorganic composition.

\begin{tabular}{|c|c|c|c|c|c|c|c|}
\hline Element & Method & Fern & Gorse & Heather & Oak & $\begin{array}{l}\text { White } \\
\text { broom }\end{array}$ & $\begin{array}{l}\text { Yellow } \\
\text { broom }\end{array}$ \\
\hline \multicolumn{2}{|c|}{$\begin{array}{l}\text { Main elemental } \\
\text { composition }\end{array}$} & \multicolumn{6}{|l|}{$\% w$} \\
\hline $\mathrm{C}$ & $\begin{array}{l}X P \text { CEN/ } \\
\text { TS15104 }\end{array}$ & 47.5 & 50.0 & 52.3 & 47.2 & 47.8 & 49.2 \\
\hline $\mathrm{H}$ & $\begin{array}{l}X P \text { CEN/ } \\
\text { TS15105 }\end{array}$ & 5.8 & 6.4 & 6.4 & 5.9 & 6.4 & 6.3 \\
\hline $\mathrm{N}$ & $\begin{array}{l}\text { XP CEN/ } \\
\text { TS15107 }\end{array}$ & 0.6 & 1.1 & 0.7 & 0.7 & 0.9 & 1.0 \\
\hline $\mathrm{O}$ & $\begin{array}{l}\text { By } \\
\text { difference }\end{array}$ & 42.4 & 41.7 & 40.0 & 44.2 & 43.9 & 43.2 \\
\hline \multicolumn{2}{|c|}{$\begin{array}{l}\text { Main inorganic ash } \\
\text { composition }\end{array}$} & \multicolumn{3}{|c|}{ g/Kg (biomass) } & & & \\
\hline $\mathrm{Al}$ & XP CEN/ & 2.9 & 10.3 & 14.4 & 2.1 & 4.3 & 10.6 \\
\hline $\mathrm{Ca}$ & TS 15290 & 63.0 & 136.5 & 98.7 & 239.3 & 121.1 & 118.5 \\
\hline $\mathrm{Cu}$ & & 0.2 & 0.5 & 0.1 & 0.1 & 0.4 & 0.1 \\
\hline $\mathrm{Fe}$ & & 2.4 & 10.2 & 10.8 & 2.5 & 6.3 & 10.8 \\
\hline K & & 289.3 & 132.9 & 213.8 & 101.7 & 279.2 & 229.9 \\
\hline $\mathrm{Mg}$ & & 24.5 & 55.4 & 52.1 & 18.6 & 66.8 & 80.7 \\
\hline Mn & & 2.2 & 9.4 & 24.2 & 4.4 & 5.0 & 10.5 \\
\hline $\mathrm{Na}$ & & 50.2 & 91.9 & 21.7 & 3.9 & 3.8 & 14.4 \\
\hline $\mathrm{Ni}$ & & 0.2 & $<0.1$ & 0.1 & $<0.1$ & 0.1 & 0.1 \\
\hline$P$ & & 27.2 & 39.7 & 41.1 & 19.7 & 34.8 & 36.3 \\
\hline $\mathrm{Si}$ & & 79.4 & 39.3 & 74.6 & 11.0 & 10.4 & 32.9 \\
\hline $\mathrm{Zn}$ & & 0.5 & 2.3 & 1.0 & 0.9 & 1.2 & 1.2 \\
\hline
\end{tabular}

\%w: mass percentage.

Biomass chemical organic and inorganic composition was measured as described by (da Silva Perez et al., 2015) (Tables 1 and 2). However, cellulose and hemicellulose content was not calculated, but only reported as "Polysaccharides content" in Table 1. Indeed, part of glucose content measured could belong to hemicelluloses, especially xyloglucans and galactoglucomannas. To our knowledge, no detailed information exists about the chemical composition of hemicelluloses for most of the biomasses studied in this work, which prevents us from estimating cellulose and hemicelluloses content. Values are presented in a weight-moisture-free basis (\% wmf).

Biomass macromolecular composition is within the range of variation observed for other biomasses studied in the literature (da Silva Perez et al., 2015; González Martínez et al., 2018; Vassilev et al., 2012, 2010).

Lignin content values are in the typical range of other biomasses in the literature, except for heather (around 36\%). Polysaccharides content of fern and gorse is similar to that obtained for oak. Contrary, quite high values were measured for the two brooms, especially for yellow broom (around 68\%). On the other hand, due to high lignin and extractive content, the polysaccharide content of heather is considerably lower than that of the other biomasses.

The extractives content of the 6 biomasses is quite high, which is typically a characteristic of agricultural and tannin-containing biomasses, such as oak (da Silva Perez et al., 2015; González Martínez et al., 2018). The valorization of the molecules contained in the extractives fraction could be the object of a more thorough study, considering its composition and the suitable extraction method from biomass (Detcheberry et al., 2016).

The sugar composition present in the polysaccharides of the different biomasses is similar for glucose $(58-65 \%)$, but presents some differences when the other sugars content is analyzed. Xylose is present in high proportions for all biomasses (24-35\%), except for fern, which presents similar proportions of xylose and mannose. This latter is completely absent in other biomasses. Galactose and arabinose content is lower than glucose and xylose content, and present some variation between the biomasses. The acetyl group content is similar for all biomasses, although fern presents smaller values. As a consequence of these observations, fern hemicelluloses seem to be a mixture of xylans and (galacto)glucomannans, similarly to agricultural biomasses. The other biomasses seem to contain predominantly xylans (eventually glucoxylans for the shrub biomasses). The presence of arabinose and galactose could be explained by the presence of arabinogalactans type II, generally found in herbal plants (Ebringerová et al., 2005).

Ash content is low for all biomasses except for fern, whose ash content is higher and closer to that of agricultural biomasses, such as wheat straw and sunflower shells, and herbaceous crops, such as miscanthus and reed canary grass, previously reported in the literature (Table 1). In the case of oak, the ash content is higher than that reported for deciduous trees in the literature, typically below $2.5 \% \mathrm{wmf}$ (González Martínez et al., 2018). This might be due to the presence of leaves and thin trunks with a high percentage of bark in the studied oak (da Silva Perez et al., 2015; Vassilev et al., 2012).

Biomass elemental composition was measured following typical standards (Table 2). Ash composition was measured through Inductively Coupled Plasma Atomic Emission Spectroscopy (ICP-AES) after mineralization for all inorganic species except for silicon, which was measured after alkaline melting, as proposed by Meyer and Bloom (1993).

A similar main elemental composition was found for the biomasses of study, which remains in the same order of magnitude of that reported in previous studies (da Silva Perez et al., 2015; Dupont et al., 2016; Vassilev et al., 2012). Differences were observed in the main inorganics content, slightly lower for the two broom species. Potassium content was lower for gorse and oak, while the calcium content was higher for these biomasses compared to the other biomasses of study. 


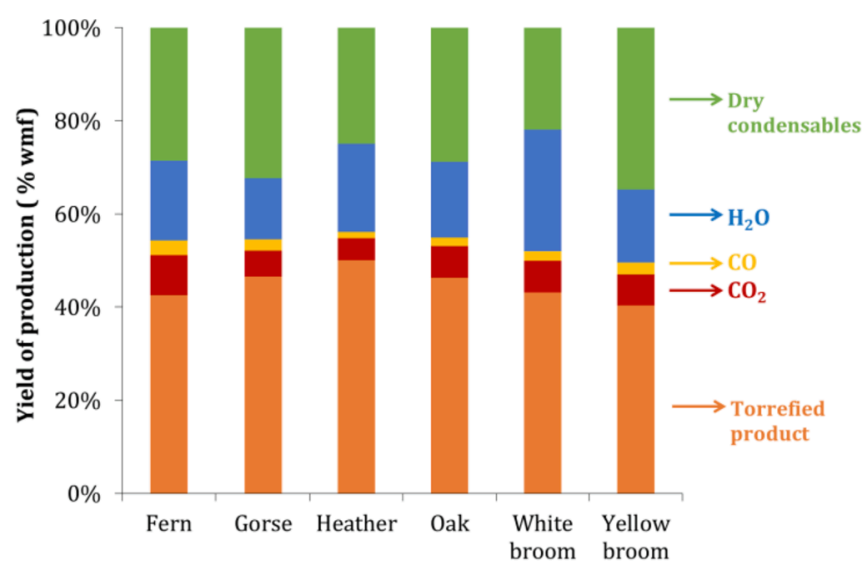

Fig. 1. Mass balance of the torrefaction products for the torrefaction experiments in TORNADE device.

As a result, the macromolecular composition of the biomasses of study seems close to that of deciduous trees for all biomasses except for fern, whose composition seems closer to that of agricultural biomasses and herbaceous crops, such as wheat straw and miscanthus. The main elemental composition of the biomasses remains quite similar.

\subsection{Mass balance of the torrefaction products}

The mass balances (Fig. 1) show a similar yield of torrefied solid for all biomasses, going from $40.3 \% \mathrm{wmf}$ of remaining solid for yellow broom to $50.1 \% \mathrm{wmf}$ for heather. This remaining solid mass is slightly lower to that of torrefaction experiments on wood and agricultural biomasses reported in the literature and carried out at equivalent temperature and residence time conditions (Nocquet, 2012; Prins et al., 2006a; van der Stelt, 2011).

The yield of condensable products, including water, is similar for all biomasses (around $45 \% \mathrm{wmf}$ ), except for brooms. In this case, the total production of condensable species is $50.4 \% \mathrm{wmf}$ for yellow broom and $47.9 \% \mathrm{wmf}$ for white broom. The composition in water of the condensable fraction is between $28.8 \% \mathrm{wmf}$ for gorse and $37.4 \% \mathrm{wmf}$ for fern, with the exception of white broom, whose water content is $54.3 \%$ wmf. This high water content in the condensable fraction may diminish the interest of its valorization (Bergman et al., 2015; Lê Thành et al., 2015).

The permanent gas production, mainly composed by $\mathrm{CO}$ and $\mathrm{CO}_{2}$, is significantly higher for fern (11.9\%wmf) and lower for heather $(6.0 \%$ wmf), compared to the other biomasses. The ratio $\mathrm{CO}_{2} / \mathrm{CO}$ is between 2.4 for gorse and 3.8 for oak, which remains in the same order of magnitude as previous studies in the literature (Nocquet et al., 2014a; Prins et al., 2006b; Sarvaramini et al., 2014).

The mass balances of these preliminary tests pointed out the production of a significant amount of gaseous products in the condensable fraction. The interest of recovering these compounds is conditioned by their nature and amount of production in function of the torrefaction operating conditions (Detcheberry et al., 2016; Lê Thành et al., 2015; Rodriguez Alonso, 2015). They will be further studied in TGA-GC/MS experiments. The direct combustion of the gaseous phase for the direct heating of the process, as it was typically proposed in some torrefaction industrial units, was evaluated through the $\mathrm{CO}_{2} / \mathrm{CO}$ ratio (Bergman et al., 2015). In this case, even if the $\mathrm{CO}_{2} / \mathrm{CO}$ ratio remains interesting, the high moisture content of the gases and the lower $\mathrm{CO}$ and $\mathrm{CO}_{2}$ content, especially in the case of white broom, might have a negative impact in the direct burning of the torrefaction permanent gases for process pre-heating.

\subsection{Torrefied solid}

\subsubsection{Evolution of solid mass versus temperature and time}

The remaining solid mass was between $75.6 \%$ wmf for yellow broom and $69.2 \% \mathrm{wmf}$ for fern at the end of the non-isothermal torrefaction $\left(200-300^{\circ} \mathrm{C}, 3^{\circ} \mathrm{C} \cdot \mathrm{min}^{-1}\right.$, Fig. 2, left). After the isothermal step, the remaining solid mass was between $57.9 \% \mathrm{wmf}$ for heather and $47.3 \% \mathrm{wmf}$ for yellow broom $\left(300^{\circ} \mathrm{C}, 30 \mathrm{~min}\right.$, Fig. 2, left).

Concerning the kinetics of the solid transformation, similar profiles were found for the investigated biomasses, except for fern, both in terms of solid mass loss and degradation rates (Fig. 2, right). In the non-isothermal torrefaction, the solid degradation is characterized by an acceleration of the mass loss until around $250^{\circ} \mathrm{C}$, followed by a slower acceleration until the end of the non-isothermal torrefaction. In the isothermal step, the mass loss progressively decelerates. In the case of fern, the change in mass loss acceleration at intermediate torrefaction temperatures is less remarkable, reaching higher values of the degradation rate at around $300{ }^{\circ} \mathrm{C}(2.5 \%$ wmf $\min ^{-1}$ compared to $1.4-1.7 \%$ wmf. $\min ^{-1}$ for the other biomasses). Furthermore, the deceleration in the isothermal step is more accentuated, nearly tending to zero after $30 \mathrm{~min}$ at $300^{\circ} \mathrm{C}$.

By comparing these results with previous studies, the solid degradation profiles of all biomasses appear to be close to the typical profile of deciduous trees. The exception is for the solid degradation profile of fern, which seems between the typical profiles of coniferous trees and wheat straw (González Martínez et al., 2018). This may be explained by fern composition, characterized by a high ash content, typical of agricultural biomasses, and a lower ratio xylose/mannose content in hemicellulose sugars, typical of coniferous trees.

Regarding these results, the valorization through mobile torrefaction
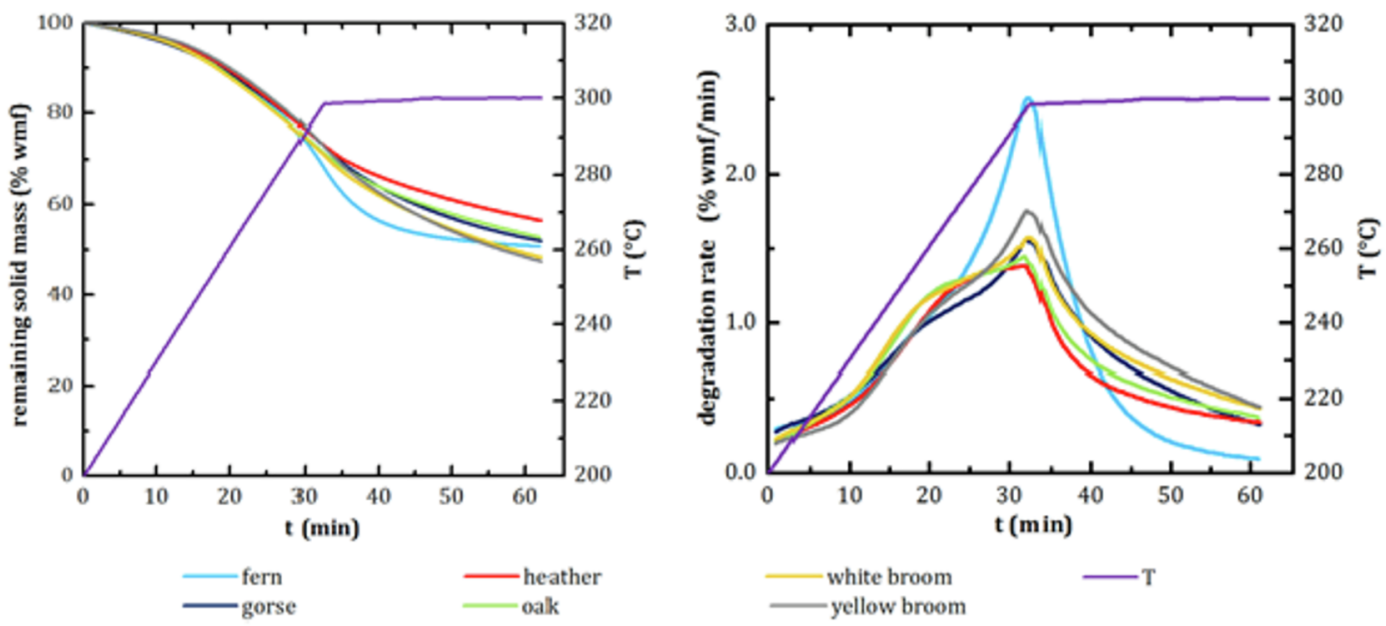

Fig. 2. Remaining solid mass (left) and degradation rate (right) versus time and temperature obtained during torrefaction. 

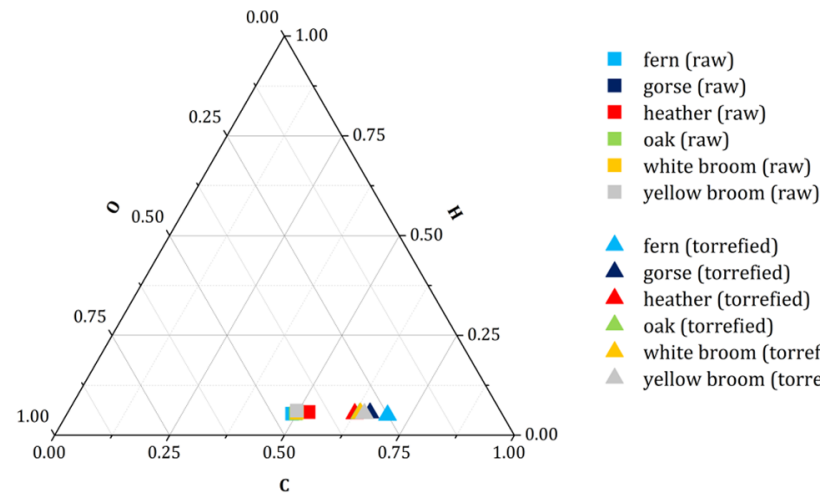

A fern (torrefied)

$\Delta$ gorse (torrefied)

heather (torrefied)

$\Delta$ oak (torrefied)

$\Delta$ white broom (torrefied)

yellow broom (torrefied)

Fig. 3. Ternary diagram of $\mathrm{CHO}$ elemental composition of raw biomass and torrefied biomass in TGA-GC/MS.

units of these biomasses or of their mixture appears to be promising. However, complementary tests would be required to confirm the feasibility of this valorization, including density measurements, as well as pelletizing, flowability and grindability tests. The yield of the solid transformation in torrefaction can be predicted by the solid kinetics curves obtained from the TGA experiments. Fern can grow either separated from shrublands, in wetter and darker areas typical of the caducifolius forest, or mixed with these species. The natural drying of these biomasses makes their moisture content uniform, even for fern (Table 1). This criterion may impact their degradation in torrefaction in a higher extent than their macromolecular composition, which is similar.

\subsubsection{Characterization of the torrefied solid}

The quality of the solid product after torrefaction was evaluated in terms of evolution in carbon (C), hydrogen $(\mathrm{H})$ and oxygen $(\mathrm{O})$ composition (Fig. 3). The results show a relative increase of the $\mathrm{C}$ content from $19.6 \%$ for heather to $42.6 \%$ for fern. This can be explained by the higher percentage of permanent gases $\left(\mathrm{CO}, \mathrm{CO}_{2}\right)$ produced in fern torrefaction compared to heather torrefaction. The $\mathrm{H}$ composition was very little affected after torrefaction, except for yellow broom, for which it decreased by about $11.8 \%$. These results are in agreement with previous studies (da Silva Perez et al., 2015; González Martínez et al., 2018; Nocquet et al., 2014a) and confirm the slight differences in terms of elemental composition of biomasses biologically close.

The torrefied solid from TGA-GC/MS experiments was also characterized in terms of calorific value. The higher heating value (HHV) was measured for the raw biomasses through ASTM standard D586511a (Table 3). However, the low amounts of torrefied material derived from the TGA-GC/MS experiment, only a few mg, did not allow to directly measure the calorific value of the final torrefied product. As a result, it was estimated through the elemental composition of the torrefied solid thanks to Boie's correlation (Boie, 1953; Peduzzi et al., 2014). The HHV was also estimated for the raw materials, so as to compare the calculated and the measured values. The estimated absolute error for the HHV of biomass fuels determined by Boie's correlation is around $3.5 \%$ (about $0.6 \mathrm{MJ} \cdot \mathrm{kg}^{-1}$ ) (Sheng and Azevedo, 2005), while the reproducibility limit of the experimental measurement following

Table 3

High Heating Value (HHV) of the selected biomasses before and after torrefaction in TGA-GC/MS on dry basis.

\begin{tabular}{llllllll}
\hline & unit & Fern & Gorse & Heather & Oak & $\begin{array}{c}\text { White } \\
\text { broom }\end{array}$ & $\begin{array}{c}\text { Yellow } \\
\text { broom }\end{array}$ \\
\hline Raw biomasses & & & & & & & \\
HHV measured & $\mathrm{MJ} \mathrm{Kg}^{-1}$ & 17.8 & 19.6 & 19.9 & 16.8 & 19.1 & 18.6 \\
$\begin{array}{l}\text { HHV calculated } \\
\text { Torrefied biomasses (TGA-GC/MS) } \\
\text { HHV calculated }\end{array}$ & $\mathrm{MJ}^{-1} \mathrm{Kg}^{-1}$ & 24.8 & 25.3 & 24.0 & 23.3 & 24.5 & 24.8 \\
\hline
\end{tabular}

Table 4

Quantified chemical compounds in biomass torrefaction experiments in TGA$\mathrm{GC} / \mathrm{MS}$, with their characteristic $\mathrm{m} / \mathrm{z}$.

\begin{tabular}{llll}
\hline $\mathrm{m} / \mathrm{z}$ & Chemical compound & $\mathrm{m} / \mathrm{z}$ & Chemical compound \\
\hline Acids & & Phenols & \\
43 & acetic acid & 94 & phenol \\
45 & formic acid & 109 & phenol, 2-methoxy (guaiacol) \\
74 & propionic acid & 110 & cathecol \\
Furans & & 150 & 2-methoxy-4-vinylphenol \\
55 & 2(5H)-furanone & 151 & vanillin \\
68 & furan & 154 & phenol, 2,6-dimethoxy- (syringol) \\
95 & acetylfuran & 164 & isoeugenol (cis + trans) \\
95 & 3-furaldehyde & 164 & eugenol \\
96 & furfural & Linear ketones \\
98 & 2-furanmethanol & 43 & 2,3-pentanedione \\
Alcohols & & 43 & 2-propanone,1-(acetyloxy)- \\
31 & methanol & 43 & hydroxyacetone \\
Aldehydes & & \multicolumn{2}{c}{ Cyclic ketones } \\
30 & formaldehyde & 96 & 4-cyclopentene-1,3-dione \\
\hline \multicolumn{4}{c}{} \\
\hline
\end{tabular}

the European Standard is about $0.3 \mathrm{MJ} \cdot \mathrm{Kg}^{-1}$ (European Committee for Standardization, 2009).

The high heating value (HHV) of the raw materials is comprised between $17.8 \mathrm{MJ}^{\mathrm{kg}}{ }^{-1}$ for fern and $19.9 \mathrm{MJ} \cdot \mathrm{kg}^{-1}$ for heather. They are in agreement with previous studies (Tumuluru et al., 2011). Except for fern, the energy content of the biomasses is in the same order of magnitude as that of wood, represented here by oak. The results after torrefaction show an increase of the HHV of around 30\% for all biomasses, except for heather (19\%) and for fern (42\%). The torrefied product would present a rather homogeneous HHV around $25 \mathrm{MJ} \cdot \mathrm{kg}^{-1}$.

\subsection{Volatile species released}

\subsubsection{Quantified volatile species}

23 chemical compounds were quantified in GC/MS (Table 4). The quantified chemical compounds include acids, furans, phenols, ketones, alcohols and aldehydes, and are in agreement with previous studies (Collard and Blin, 2014; Lê Thành et al., 2015; Nocquet et al., 2014b).

\subsubsection{Total volatile species production}

The total volatile species production was firstly calculated through the integration of the area below the profile of production curve for each volatile species in function of the torrefaction temperature. The total quantified volatile species production goes from $2.5 \mathrm{mg}$ for heather to $1.5 \mathrm{mg}$ for oak, released by a mass of biomass transformed from $265 \mathrm{mg}$ for heather to $308 \mathrm{mg}$ for oak (all experiments were normalized to $1 \mathrm{~g}$ of initial biomass for comparison). This quantified fraction can be considered as acceptable as only a part of the volatile species could be identified from those released in torrefaction. The composition of the volatile species mixture is in agreement with previous studies (Lê Thành et al., 2015; Nocquet et al., 2014b).

Fig. 4 shows that acids were the major chemical compounds quantified, followed by alcohols and aldehydes. Furans, phenols and ketones

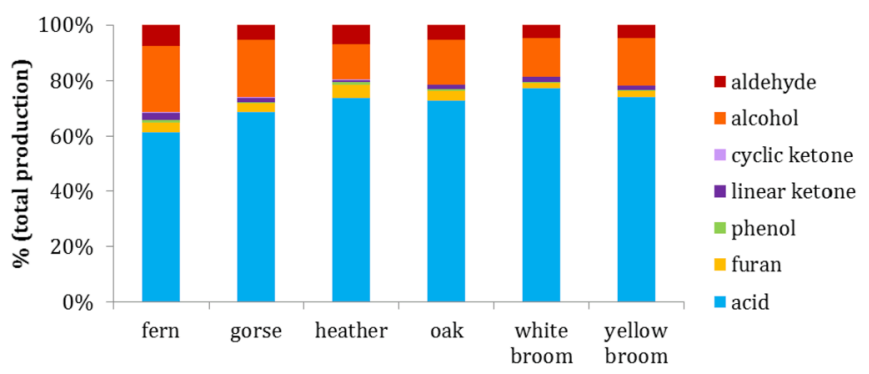

Fig. 4. Distribution of the total production of volatile species per chemical family in biomass torrefaction in TGA-GC/MS. 

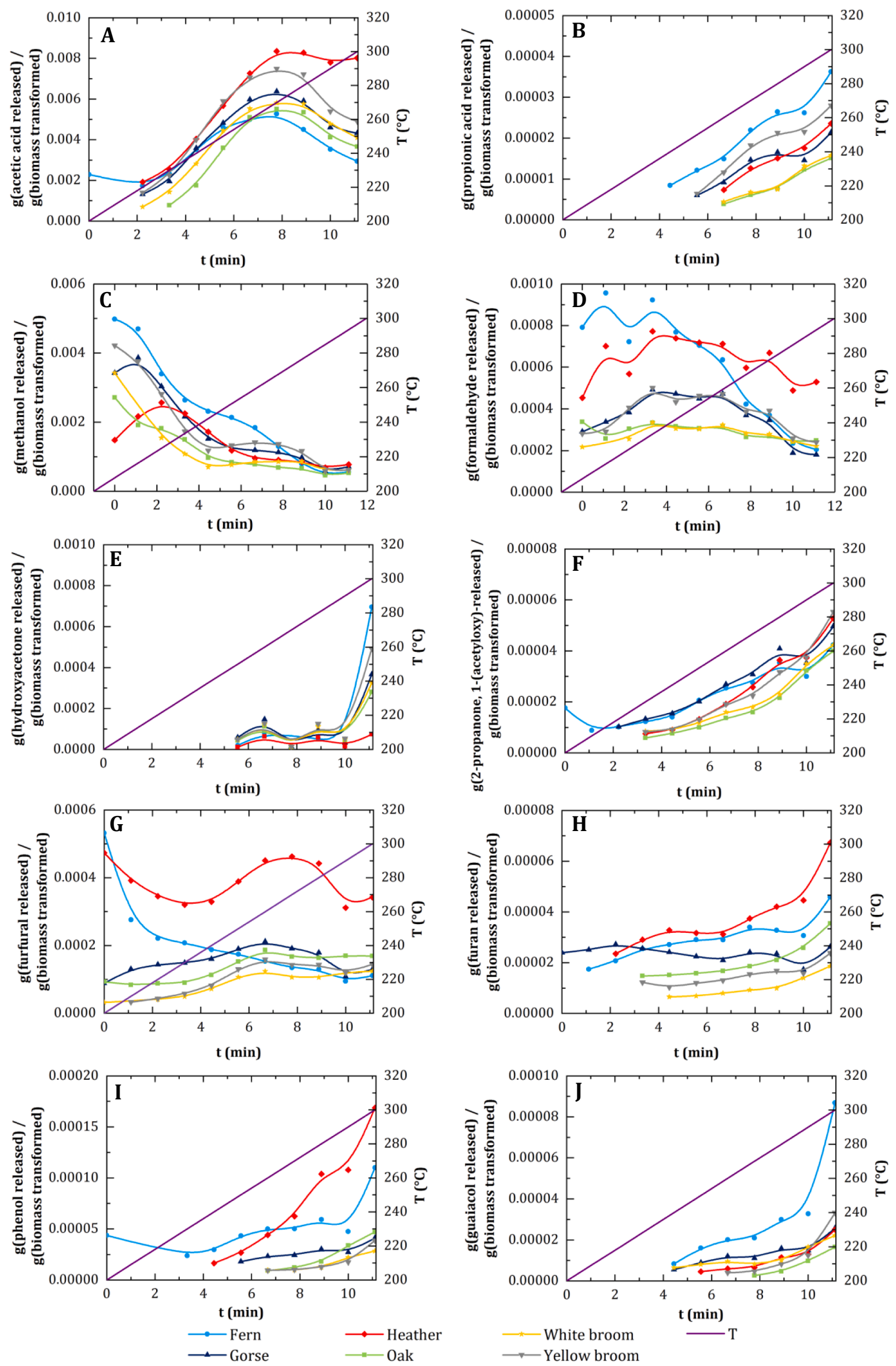

Fig. 5. Production profiles of volatile species quantified in biomass torrefaction in TGA-GC/MS $\left(200\right.$ to $\left.300{ }^{\circ} \mathrm{C}, 3^{\circ} \mathrm{C} \cdot \mathrm{min}^{-1}\right)$. 
could be detected in minor amounts. The non-identified volatile fraction is expected to contain also these categories of chemical species, as well as sugar molecules, which could not be identified with o ur chromatography column.

The major volatile species detected were acetic acid (from 60.7 to $77.1 \%$ of the total volatile species quantified), methanol (12.6-23.6\%), formaldehyde (4.8-7.7\%), furfural (1.6-4.3\%) and hydroxyacetone (0.3-1.2\%). Minor amounts of chemical compounds that can present an interesting added-value as green chemicals were also measured, such as vanillin (Walton et al., 2003) and eugenol/isoeugenol (Koeduka et al., 2006).

\subsubsection{Production profiles of the volatile species released}

The production profiles i $\mathrm{n} f$ unction of $\mathrm{t}$ he $\mathrm{t}$ orrefaction $\mathrm{t}$ ime and temperature were studied for the quantified volatile species. They allow determining the theoretical optimum torrefaction conditions for adjusting the production of a given chemical compound. The production profiles o btained $\mathrm{f}$ or a $\mathrm{n}$ umber o $\mathrm{f}$ he $\mathrm{v}$ olatile $\mathrm{s}$ pecies $\mathrm{q}$ uantified are presented in Fig. 5.

Acetic acid production is higher for heather and brooms, compared to that of fern (Fig. 5A), which can be explained by the slightly lower acetyl content of fern (5.2\% compared to $6.0-6.8 \%)$. Its maximum of production is at around $270{ }^{\circ} \mathrm{C}$, which corresponds to the degradation of hemicellulose sugars, containing acetyl groups in terminal positions (Rodriguez Alonso et al., 2016; Wang et al., 2015). No other volatile species present a production profile close to that of acetic acid. Formic and propionic acids were also detected. In the first $\mathrm{c}$ ase, o nly small amounts were detected at $270-300{ }^{\circ} \mathrm{C}$ for heather and fern, below $1 \mathrm{mg}$ (formic acid produced at a given $\mathrm{T}$ ) per $\mathrm{g}$ (biomass transformed). This compound was reported to be formed from the breaking of carboxylic acid function of the hexuronic acids in hemicelluloses (Shen et al., 2010). Propionic acid presents an increasing production with increasing torrefaction temperature (Fig. 5B).

Methanol also presents a production profile whose maximum is at low torrefaction temperatures (Fig. 5C). It is expected to be mainly produced from the fragmentation of the methoxy group of the 4-Omethyl- $\alpha$-D glucuronic acid from hemicelluloses (Prins et al., 2006b; Shen et al., 2010). Even if it is mainly produced by fern, the highest hemicellulose content was found for brooms. A more detailed hemicellulose composition would be required to explain this behavior.

Formaldehyde is characterized by a rather constant production profile in $\mathrm{f}$ unction of t emperature (Fig. $5 \mathrm{D}$ ). It $\mathrm{w}$ as r eported to be released in lignin decomposition, more precisely from the fragmentation between $C \beta$ and $C \gamma$ in lignin structure, when the hydroxyl group is linked to the $C_{\gamma}$ (Jakab et al., 1995; Liu et al., 2008). The results showed a higher production for heather and fern, followed by brooms, oak and gorse. This production is consistent with the higher lignin content of heather $(37.1 \%)$ and the lower for oak $(27.0 \%)$ and brooms (25.5\% for white broom, $22.4 \%$ for yellow broom). However, gorse and fern have similar lignin content (32.2\% and $31.7 \%$, respectively) and the formaldehyde production is different at lower temperatures (below $260^{\circ} \mathrm{C}$ ). This could indicate a difference i $\mathrm{n}$ lignin $\mathrm{s}$ tructure between fern, probably closer to agricultural biomasses, and gorse, which seemed similar to deciduous trees. Indeed, deciduous trees lignin is composed by G - (guaiacyl-) and S- (syringyl-) units (Kirk-Othmer, 1999), while herbaceous plant lignin also contains H- (phenyl-) units (Sequeiros and Labidi, 2017).

The profile of production of hydroxyacetone s tarts at intermediate torrefaction temperatures and presents two local minima at 270 and $290^{\circ} \mathrm{C}$, followed by an increase in the production at $300^{\circ} \mathrm{C}$ (Fig. 5E). It is expected to be produced by hemicelluloses (Collard and Blin, 2014), which explains its release at intermediate torrefaction temperatures, and by cellulose, which could contribute to the rise in the production at $300^{\circ} \mathrm{C}$ (Shen and $\mathrm{Gu}, 2009$ ). On the other hand, the production of linear ketones, such as 2,3-pentanedione and 2-propanone,1-(acetyloxy)-, increases with the increasing temperature in an equivalent order of magnitude for the 6 biomasses, below $1 \mathrm{mg}$ (compound produced at a given $\mathrm{T}$ ) per $\mathrm{g}$ (biomass transformed) (Fig. 5F). They would mainly come from the defragmentation of hemicelluloses.

Furfural is the main furan detected (Fig. 5G). These compounds were reported to be mostly derived from glucan from cellulose (Shen and $\mathrm{Gu}, 2009$ ), but they can also be released in hemicelluloses depolymerization (Peng and $\mathrm{Wu}, 2010$ ). The production profile of the furans detected is characterized by an increase in the production with the increasing torrefaction temperature (Fig. 5H), except for furfural, whose production is only slightly increasing with temperature (Fig. 5G). This is in agreement with previous studies which have reported furfural release from low temperatures (Shen et al., 2010). As for all the furans detected, the highest furfural production was quantified for heather and fern, which contrasts with the fact that these are the biomass with the lower cellulose and hemicelluloses content.

The production profile of phenol starts at intermediate torrefaction temperatures around $250^{\circ} \mathrm{C}$ and shows an increasing production until $300{ }^{\circ} \mathrm{C}$. The maximum production of phenol was measured for heather and fern, as in the case of formaldehyde (Fig. 5I). Phenol was the major phenolic compound detected, followed by guaiacol (about half of the phenol production, Fig. 5J). Other phenolic compounds, such as isoeugenol, syringol and vanillin were detected in minor amounts between 280 and $300^{\circ} \mathrm{C}$. Cathecol, eugenol and 2-methoxy-4-vinylphenol did not enable to represent a production profile, as they were only detected in small amounts at $300{ }^{\circ} \mathrm{C}$. Phenolic compounds were reported to be released in lignin defragmentation (Bai et al., 2014; Ohra-aho et al., 2013).

Regarding the process, the composition of the volatile species fraction of the 6 biomasses in torrefaction is similar. This might suggest that the condensable fraction would have a similar composition by directly torrefying a mixture of these biomasses, as they are present in the nature. At the same time, the profile of formation and the temperature of the maximum production suggest the origin of the volatile species from biomass macromolecular components. Indeed, the production profiles of the volatile species are a useful tool to set the optimum operating temperature which enhances the proportion of a targeted chemical compound.

\section{Conclusions}

In this work, 6 biomasses, including 5 shrub species and a deciduous tree, were identified in the area of study to be potentially valorized through torrefaction, due to their availability and their usual involvement in wildland fires in the South of Europe. The obtained results showed that all biomasses present similar properties and kinetic behavior in torrefaction, closer to that of deciduous trees, and slightly different for fern, rather close to agricultural biomasses. This last material usually grows separately from the other biomasses of study and is considered to present a low fire risk. Consequently, the direct in-situ valorization of these biomasses through torrefaction mobile units seems promising and suitable according to the characteristics of their production. However, complementary studies on biomass density, flowability, grindability and pelletizing ability would be required to confirm the feasibility of the process.

By analyzing in detail the obtained results, the mass balance of the products at typical torrefaction conditions $\left(300^{\circ} \mathrm{C}, 40 \mathrm{~min}\right)$ pointed out a high volatile species production. The composition of this fraction, characterized through TGA-GC/MS $\left(200\right.$ to $300^{\circ} \mathrm{C}, 3^{\circ} \mathrm{C} \cdot \mathrm{min}^{-1}$ ), showed that the main volatile species detected were acetic acid, methanol, formaldehyde, furfural, hydroxyacetone and phenol. The production profiles of the volatile species released in torrefaction allowed confirming their macromolecular origin. Besides, the maximum of the production of each volatile species production profile indicated the optimum conditions for enhancing its release in torrefaction. 


\section{Acknowledgments}

This project has received funding from the European Union Horizon 2020 research and innovation program under grant agreement No 637020 - MOBILE FLIP.

We would like to thank Luis Míguez, for his work about the biological diversity in Chandrexa de Queixa. We would also specially thank Tomás González Lamelas, for helping in biomass harvesting and preparation, as well as for his involvement in the valorization of this region.

\section{References}

Agar, D.A., 2017. A comparative economic analysis of torrefied pellet production based on state-of-the-art pellets. Biomass Bioenergy 97, 155-161. https://doi.org/10.1016/ j.biombioe. 2016.12.019.

Bados, R., Esteban, L.S., Pérez, P., Corredor, R., Zamora, V., Mediavilla, I., Carrasco, J.E., Blasco, I., Calero, R., Velasco, H., Carrascosa, A., 2016. Scrub harvesting trials for energy purposes, Presented at the European Biomass Conference and Exhibition Proceedings. pp. 270-272.

Bai, X., Kim, K.H., Brown, R.C., Dalluge, E., Hutchinson, C., Lee, Y.J., Dalluge, D., 2014. Formation of phenolic oligomers during fast pyrolysis of lignin. Fuel 128, 170-179. https://doi.org/10.1016/j.fuel.2014.03.013.

Bellot Rodríguez, F., 1966. La vegetación de Galicia. Anales del Instituto Botánico A.J. Cavanilles. Consejo Superior de Investigaciones Científicas, Madrid.

Bergman, P.C.A., Boersma, A.R., Zwart, R.W.R., Kiel, J.H.A., 2015. Torrefaction for Biomass Co-firing in Existing Coal-Fired Power Stations "BIOCOAL" (No. ECN-C-05013). Energy research Centre of the Netherlands (ECN).

Blanco Casal, A., García Arias, A., Valdês Paços, B., Carballido Presas, X., Paz Franco, T., 2017. O Monte Galego. Sermos Galiza, Santiago de Compostela.

Boie, W., 1953. Fuel technology calculations. Energ. Tech. 3, 309-316.

Bridgeman, T.G., Jones, J.M., Shield, I., Williams, P.T., 2008. Torrefaction of reed canary grass, wheat straw and willow to enhance solid fuel qualities and combustion properties. Fuel 87, 844-856. https://doi.org/10.1016/j.fuel.2007.05.041.

Centro de Coordinación de la Información Nacional sobre Incendios Forestales, 2017. Avance informativo de los incendios forestales del 1 de enero al 31 de diciembre de 2017.

Collard, F.-X., Blin, J., 2014. A review on pyrolysis of biomass constituents: mechanisms and composition of the products obtained from the conversion of cellulose, hemicelluloses and lignin. Renew. Sustain. Energy Rev. 38, 594-608. https://doi.org/10. 1016/j.rser.2014.06.013.

Cremers, M., Koppejan, J., Middelkamp, J., Witkamp, J., Sokhansanj, S., Melin, S., Madrali, S., 2015. Status Overview of Torrefaction Technologies - A Review of the Commercialisation Status of Biomass Torrefaction (IEA Bioenergy: Task 32: Biomass Combustion and Cofiring).

da Silva Perez, D., Dupont, C., Guillemain, A., Jacob, S., Labalette, F., Briand, S., Marsac, S., Guerrini, O., Broust, F., Commandre, J.-M., 2015. Characterisation of the most representative agricultural and forestry biomasses in France for gasification. Waste Biomass Valorization 6, 515-526. https://doi.org/10.1007/s12649-015-9374-3.

Detcheberry, M., Destrac, P., Massebeuf, S., Baudouin, O., Gerbaud, V., Condoret, J.-S., Meyer, X.-M., 2016. Thermodynamic modeling of the condensable fraction of a gaseous effluent from lignocellulosic biomass torrefaction. Fluid Phase Equilib. 409, 242-255. https://doi.org/10.1016/j.fluid.2015.09.025.

Dupont, C., Jacob, S., Marrakchy, K.O., Hognon, C., Grateau, M., Labalette, F., Da Silva Perez, D., 2016. How inorganic elements of biomass influence char steam gasification kinetics. Energy 109, 430-435. https://doi.org/10.1016/j.energy.2016.04.094.

E4tech, 2009. Review of Technologies for Gasification of Biomass and Wastes (Final Raport) - NNFCC Project 09/008.

Ebringerová, A., Hromádková, Z., Heinze, T., 2005. Hemicellulose. In: Heinze, T. (Ed.), Polysaccharides I, Advances in Polymer Science. Springer Berlin Heidelberg, pp. 1-67. https://doi.org/10.1007/b136816.

European Committee for Standardization, 2009. EN 14918:2009. Solid Biofuels Determination of Calorific Value.

Evans, G.J., Bellinder, R.R., Hahn, R.R., 2011. Integration of vinegar for in-row weed control in transplanted bell pepper and broccoli. Weed Technol. 25, 459-465. https://doi.org/10.1614/WT-D-10-00167.1.

Fischer, H., Kuzyakov, Y., 2010. Sorption, microbial uptake and decomposition of acetate in soil: transformations revealed by position-specific 14C labeling. Soil Biol. Biochem. 42, 186-192. https://doi.org/10.1016/j.soilbio.2009.10.015.

Fisher, E.M., Dupont, C., Darvell, L.I., Commandré, J.-M., Saddawi, A., Jones, J.M., Grateau, M., Nocquet, T., Salvador, S., 2012. Combustion and gasification characteristics of chars from raw and torrefied biomass. Bioresour. Technol. 119, 157-165. https://doi.org/10.1016/j.biortech.2012.05.109.

García, R., González-Vázquez, M.P., Pevida, C., Rubiera, F., 2018. Pelletization properties of raw and torrefied pine sawdust: effect of co-pelletization, temperature, moisture content and glycerol addition. Fuel 215, 290-297. https://doi.org/10.1016/j.fuel. 2017.11.027.

González Martínez, M., Dupont, C., Thiéry, S., Meyer, X.-M., Gourdon, C., 2018. Impact of biomass diversity on torrefaction: study of solid conversion and volatile species formation through an innovative TGA-GC/MS apparatus. Biomass Bioenergy 119, 43-53. https://doi.org/10.1016/j.biombioe.2018.09.002.

González Martínez, M., Dupont, C., Thiery, S., Meyer, X.M., Gourdon, C., 2016.
Characteristic time analysis of biomass torrefaction phenomena - application to thermogravimetric analysis device. Chem. Eng. Trans. 50, 61-66. https://doi.org/10. 3303/CET1650011.

González-González, B.D., Sixto, H., Alberdi, I., Esteban, L., Guerrero, S., Pasalodos, M., Vázquez, A., Cañellas, I., 2017. Estimation of shrub biomass availability along two geographical transects in the Iberian Peninsula for energy purposes. Biomass Bioenergy 105, 211-218. https://doi.org/10.1016/j.biombioe.2017.07.011.

Jakab, E., Faix, O., Till, F., Székely, T., 1995. Thermogravimetry/mass spectrometry study of six lignins within the scope of an international round robin test. J. Anal. Appl. Pyrolysis 35, 167-179. https://doi.org/10.1016/0165-2370(95)00907-7.

Kavitha, B., Reddy, P.V.L., Kim, B., Lee, S.S., Pandey, S.K., Kim, K.-H., 2018. Benefits and limitations of biochar amendment in agricultural soils: a review. J. Environ. Manag. 227, 146-154. https://doi.org/10.1016/j.jenvman.2018.08.082.

Kirk-Othmer, 1999. Encyclopedia of Chemical Technology. Willey.

Koeduka, T., Fridman, E., Gang, D.R., Vassão, D.G., Jackson, B.L., Kish, C.M., Orlova, I., Spassova, S.M., Lewis, N.G., Noel, J.P., Baiga, T.J., Dudareva, N., Pichersky, E., 2006. Eugenol and isoeugenol, characteristic aromatic constituents of spices, are biosynthesized via reduction of a coniferyl alcohol ester. Proc. Natl. Acad. Sci. U. S. A 103, 10128-10133. https://doi.org/10.1073/pnas.0603732103.

Lê Thành, K., Commandré, J.-M., Valette, J., Volle, G., Meyer, M., 2015. Detailed identification and quantification of the condensable species released during torrefaction of lignocellulosic biomasses. Fuel Process. Technol. 139, 226-235. https://doi.org/ 10.1016/j.fuproc.2015.07.001.

Liu, Q., Wang, S., Zheng, Y., Luo, Z., Cen, K., 2008. Mechanism study of wood lignin pyrolysis by using TG-FTIR analysis. J. Anal. Appl. Pyrolysis 82, 170-177. https:// doi.org/10.1016/j.jaap.2008.03.007.

López González, G., 2006. Los árboles y arbustos de la península Ibérica e islas Baleares I. Mundi Prensa, Madrid.

Mediavilla, I., Borjabad, E., Fernández, M.J., Ramos, R., Pérez, P., Bados, R., Carrasco, J.E., Esteban, L.S., 2017. Biofuels from broom clearings: production and combustion in commercial boilers. Energy 141, 1845-1856. https://doi.org/10.1016/j.energy. 2017.11.112.

Meyer, M.L., Bloom, P.R., 1993. Lithium metaborate fusion for silicon, calcium, magnesium, and potassium analysis of wild rice. Plant Soil 153, 281-285.

Miguel Carneiro Ribeiro, J., Godina, R., Matias, J., Nunes, L., 2018. Future perspectives of biomass torrefaction: review of the current state-of-the-art and research development. Sustainability 10. https://doi.org/10.3390/su10072323.

Míguez Rodríguez, L.J., 2010. Chandrexa de Queixa, patrimonio natural. Deputación de Ourense.

Nocquet, T., 2012. Torréfaction du bois et de ses constituants: Expériences et modélisation des rendements en matières volatiles. Université de Toulouse, Toulouse.

Nocquet, T., Dupont, C., Commandre, J.-M., Grateau, M., Thiery, S., Salvador, S., 2014a. Volatile species release during torrefaction of wood and its macromolecular constituents: Part 1 - experimental study. Energy 72, 180-187. https://doi.org/10.1016/ j.energy.2014.02.061.

Nocquet, T., Dupont, C., Commandre, J.-M., Grateau, M., Thiery, S., Salvador, S., 2014b. Volatile species release during torrefaction of biomass and its macromolecular constituents: Part 2 - modeling study. Energy 72, 188-194. https://doi.org/10.1016/j. energy.2014.05.023.

Núñez-Regueira, L., Proupín-Castiñeiras, J., Rodríguez-Añón, J.A., 2004. Energy evaluation of forest residues originated from shrub species in Galicia. Bioresour. Technol. 91, 215-221. https://doi.org/10.1016/S0960-8524(03)00169-X.

Ohra-aho, T., Gomes, F.J.B., Colodette, J.L., Tamminen, T., 2013. S/G ratio and lignin structure among Eucalyptus hybrids determined by Py-GC/MS and nitrobenzene oxidation. J. Anal. Appl. Pyrolysis 101, 166-171. https://doi.org/10.1016/j.jaap. 2013.01.015.

Pach, M., Zanzi, R., Björnbom, E., 2002. In: Torrefied Biomass a Substitue for Wood and Charcoal. Presented at the 6th Asia-Pacific International Symposium on Combustion and Energy Utilization, Kuala Lumpur (Malaysia).

Peduzzi, E., Boissonnet, G., Haarlemmer, G., Dupont, C., Maréchal, F., 2014. Torrefaction modelling for lignocellulosic biomass conversion processes. Energy 70, 58-67. https://doi.org/10.1016/j.energy.2014.03.086.

Peng, Y., Wu, S., 2010. The structural and thermal characteristics of wheat straw hemicellulose. J. Anal. Appl. Pyrolysis 88, 134-139. https://doi.org/10.1016/j.jaap.2010. 03.006.

Pérez, S., Renedo, C.J., Ortiz, A., Delgado, F., Fernández, I., 2014. Energy potential of native shrub species in northern Spain. Renew. Energy 62, 79-83. https://doi.org/10 1016/j.renene.2013.06.048.

Prins, M.J., Ptasinski, K.J., Janssen, F.J.J.G., 2006a. Torrefaction of wood: Part 1. Weight loss kinetics. J. Anal. Appl. Pyrolysis 77, 28-34. https://doi.org/10.1016/j.jaap. 2006.01.002.

Prins, M.J., Ptasinski, K.J., Janssen, F.J.J.G., 2006b. Torrefaction of wood. Part 2. Analysis of products. J. Anal. Appl. Pyrolysis 77, 35-40. https://doi.org/10.1016/j. jaap.2006.01.001.

Rasa, K., Heikkinen, J., Hannula, M., Arstila, K., Kulju, S., Hyväluoma, J., 2018. How and why does willow biochar increase a clay soil water retention capacity? Biomass Bioenergy 119, 346-353. https://doi.org/10.1016/j.biombioe.2018.10.004.

Rodriguez Alonso, E., 2015. Contribution to the Study of Formation Mechanisms of Condensable By-Products from Torrefaction of Various Biomasses. INPT, Toulouse.

Rodriguez Alonso, E., Dupont, C., Heux, L., Da Silva Perez, D., Commandre, J.-M., Gourdon, C., 2016. Study of solid chemical evolution in torrefaction of different biomasses through solid-state 13C cross-polarization/magic angle spinning NMR (nuclear magnetic resonance) and TGA (thermogravimetric analysis). Energy 97, 381-390. https://doi.org/10.1016/j.energy.2015.12.120.

Saldarriaga, J.F., Aguado, R., Pablos, A., Amutio, M., Olazar, M., Bilbao, J., 2015. Fast characterization of biomass fuels by thermogravimetric analysis (TGA). Fuel 140, 
744-751. https://doi.org/10.1016/j.fuel.2014.10.024.

San-Miguel-Ayanz, J., Durrant, T., Boca, R., Libertà, G., Branco, A., De Rigo, D., Ferrari, D., Maianti, P., Artés Vivancos, T., Schulte, E., Loffler, P., 2017. Forest Fires in Europe, Middle East and North Africa 2016 (No. EUR 28707 EN). European Commision, Luxembourg.

Sarvaramini, A., Assima, G.P., Beaudoin, G., Larachi, F., 2014. Biomass torrefaction and $\mathrm{CO} 2$ capture using mining wastes - a new approach for reducing greenhouse gas emissions of co-firing plants. Fuel 115, 749-757. https://doi.org/10.1016/j.fuel. 2013.07.087.

Sequeiros, A., Labidi, J., 2017. Characterization and determination of the S/G ratio via Py-GC/MS of agricultural and industrial residues. Ind. Crops Prod. 97, 469-476. https://doi.org/10.1016/j.indcrop.2016.12.056.

Shen, D.K., Gu, S., 2009. The mechanism for thermal decomposition of cellulose and its main products. Bioresour. Technol. 100, 6496-6504. https://doi.org/10.1016/j. biortech.2009.06.095.

Shen, D.K., Gu, S., Bridgwater, A.V., 2010. Study on the pyrolytic behaviour of xylanbased hemicellulose using TG-FTIR and Py-GC-FTIR. J. Anal. Appl. Pyrolysis 87, 199-206. https://doi.org/10.1016/j.jaap.2009.12.001.

Sheng, C., Azevedo, J.L.T., 2005. Estimating the higher heating value of biomass fuels from basic analysis data. Biomass Bioenergy 28, 499-507. https://doi.org/10.1016/j. biombioe.2004.11.008.

Simbeck, D.R., 1993. Coal Gasification Guidebook: Status, Applications, and Technologies: TR-102034, Research Project 2221-39, Final Report. Electric Power Research Institute.

Tamminen, T., Campargue, M., Da Silva Perez, D., Dupont, C., Englund, F., Kotli, P., Larsson, S., Papadopoulou, E., Rasa, K., Raussi, T., Sajet, P., Wallin, M., 2016. Mobile and Flexible Processing of Biomass - EU Project MOBILE FLIP.

Tumuluru, J.S., Sokhansanj, S., Hess, J.R., Wright, C.T., Boardman, R.D., 2011. A review on biomass torrefaction process and product properties for energy applications. Ind. Biotechnol. 7, 384-401. https://doi.org/10.1089/ind.2011.7.384.
USDA, 2010. Wood Handbook: Wood as an Engineering Material. US Department of Agriculture.

van der Stelt, M.J.C., 2011. Chemistry and Reaction Kinetics of Biowaste Torrefaction. Technische Universiteit Eindhoven, Eindhoven.

Vassilev, S.V., Baxter, D., Andersen, L.K., Vassileva, C.G., 2010. An overview of the chemical composition of biomass. Fuel 89, 913-933. https://doi.org/10.1016/j.fuel. 2009.10.022.

Vassilev, S.V., Baxter, D., Andersen, L.K., Vassileva, C.G., Morgan, T.J., 2012. An over view of the organic and inorganic phase composition of biomass. Fuel 94, 1-33. https://doi.org/10.1016/j.fuel.2011.09.030.

Vega-Nieva, D.J., Ortiz Torres, L., Míguez Tabares, J.L., Morán, J., 2016. Measuring and predicting the slagging of woody and herbaceous mediterranean biomass fuels on a domestic pellet boiler. Energy Fuels 30, 1085-1095. https://doi.org/10.1021/acs. energyfuels.5b02495.

Viana, H., Vega-Nieva, D.J., Ortiz Torres, L., Lousada, J., Aranha, J., 2012. Fuel characterization and biomass combustion properties of selected native woody shrub species from central Portugal and NW Spain. Fuel Spec. ACS Clean Coal 102, 737-745. https://doi.org/10.1016/j.fuel.2012.06.035.

Walton, N.J., Mayer, M.J., Narbad, A., 2003. Vanillin. Phytochemistry 63, 505-515. https://doi.org/10.1016/S0031-9422(03)00149-3.

Wang, S., Ru, B., Lin, H., Sun, W., 2015. Pyrolysis behaviors of four O-acetyl-preserved hemicelluloses isolated from hardwoods and softwoods. Fuel 150, 243-251. https:// doi.org/10.1016/j.fuel.2015.02.045.

Woolf, D., Amonette, J.E., Street-Perrott, F.A., Lehmann, J., Joseph, S., 2010. Sustainable biochar to mitigate global climate change. Nat. Commun. 1, 56. https://doi.org/10. 1038/ncomms1053.

Yu, H., Zou, W., Chen, J., Chen, H., Yu, Z., Huang, J., Tang, H., Wei, X., Gao, B., 2019. Biochar amendment improves crop production in problem soils: a review. J. Environ. Manag. 232, 8-21. https://doi.org/10.1016/j.jenvman.2018.10.117. 